\title{
O PODER REgulamentaR E AS COMPETÊNCIAS NORMATIVAS CONFERIDAS À AGÊNCIA NACIONAL DE VIGILÂNCIA SANITÁRIA*
}

REGULATORY POWER AND NORMATIVE COMPETENCE OF THE

BRAZILIAN NATIONAL AGENCY OF SANITARY SURVEILLANCE

Eliana Aparecida Silva de Moraes ${ }^{(* *)}$

\section{RESUMO}

A atividade de vigilância sanitária é multifacetada. Para montar um sistema mais ágil de proteção à saúde e normatizar ações de direito sanitário, a Lei Federal n. 9.782/99 criou a Agência Nacional de Vigilância Sanitária (ANVISA), dotada de poder regulamentar.

Este poder é alvo de limitação constitucional decorrente do estado de direito, devendo-se questionar sua extensão em relação à lei. Vislumbra-se a questão do interesse da saúde pública em face do princípio da legalidade. Estando o decreto regulamentar adstrito à lei, deve, portanto, ser interpretada restritivamente a atribuição desse poder à ANVISA. A resposta a esta questão incide na idéia do direito sanitário como um direito específico, composto por regras próprias, um direito regulatório.

\section{Palavras-chave}

Poder Regulamentar, Princípio da Legalidade, Interesse Público, Vigilância Sanitária.

\section{ABSTRACT}

The sanitary surveillance activity is multidimensional. To form a nimbler health protection system and to regulate sanitary actions, the Federal

(*) Trabalho elaborado como parte dos requisitos para a obtenção do título de especialista em Direito Sanitário na Universidade de Sāo Paulo.

("*) Advogada, especialista em Direito Sanitário pela Faculdade de Saúde Pública de São Paulo, membro Efetivo do Comitê de Meio Ambiente da Ordem dos Advogados do Brasil, presidente da Associação Brasileira dos Profissionais em Vigilância Sanitária - ABPVS. 
Law $9.782 / 99$ created the National Agency of Sanitary Surveillance (ANVI$\mathrm{SA})$ endowed with regulatory power.

This power has constitutional and legal limits. Public health issues asre framed by the rule of law. Regulatory acts are bound by law. Therefore, ANVISA's power is to be restrictively interpreted. The answer to this is highlighted by Sanitary Law as a specific law branch made of particular rules, as a regulatory law.

\section{Key words}

Regulatory Power, Rule of Law, Public Interest, Sanitary Surveillance, Health Care.

\section{INTRODUÇÃO}

Considerando a grande relevância da atividade de vigilância sanitária, sobretudo no que tange ao aspecto de proteção da saúde da população, se faz importante uma análise das competências normativas conferidas por meio da Lei Federal n. 9.782/99 à Agência Nacional de Vigilância Sanitária, à vista dos princípios constitucionais norteadores do poder regulamentar, dentro das peculiaridades do direito sanitário.

\section{O SISTEMA NACIONAL DE VIGILÂNCIA SANITÁRIA}

Antes de entrarmos no tema propriamente dito, é importante tecermos algumas considerações sobre o sistema de vigilância sanitária no Brasil, cuja atividade representa a prática mais antiga de saúde pública."

O campo de atuação da vigilância sanitária é vastíssimo, podendose destacar, dentre algumas atividades, em seu aspecto de poder de polícia, de fiscalização, concessão de licença de funcionamento para estabelecimentos industriais etc., não nos esquecendo, ainda, de ressaltar o notável papel educacional que ela exerce perante a sociedade como, v. g., quando coordena campanhas de vacinações, prevenção e erradicação de doenças, dentre outras. ${ }^{(2)}$ Alguns estudiosos atribuem, ainda, uma terceira característica à atividade de vigilância sanitária, que é a da sua função normatizadora(3).

(1) EDUARDO, Maria Bernadete de Paula. "Saúde e Cidadania - Vigilãncia Sanitaria", Sảo Paulo, Fundação Peirópolis, 1998, pp. 2-4.

(2) Sobre o papel da Vigilância Sanitária, v. EDUARDO, Maria B. P., "Vigilância Sanitária", cit., pp. 3-7; MEIRELLES, Hely Lopes. "Direito Administrativo Brasileiro", 14* ed., São Paulo, Revista dos Tribunais, 1988, p. 120; LIMA, Ruy Cirne. "Principios de Direito Administrativo", 5ª ed., São Paulo, Revista dos Tribunais, 1982, pp. 118-120.

(3) EDUARDO, Maria Bernadete de Paula. "Vigilância Sanitária", cit 
A competência ${ }^{(4)}$ constitucional das ações de vigilância sanitária, por sua vez, é comum ${ }^{(5)}$ às três esferas de governo: União, Estados, Distrito Federal e Municípios ${ }^{(6)(7)}$. No que tange à legislação sobre proteção e defesa da saúde (na qual está inserida também a matéria de vigilância sanitária), esta é concorrente( ${ }^{(8)}$ entre as entidades federativas, o que significa dizer que as atuações deverão ser simultâneas e harmônicas entre si, estabelecendo o texto constitucional que caberá à União legislar sobre normas gerais (art. 24, $\S 1^{\circ}$ ), ao Estado suplementar essas normas no que couber $\left(\S 2^{\circ}\right)$, assim como suprir omissões legislativas federais $\left(\S 3^{\circ}\right)$ e, finalmente, ao Município legislar sobre os assuntos de interesse local ${ }^{(9)}$ (art. 30 , inciso l), bem como suplementar a legislação federal e estadual pertinente à saúde, naquilo que o interesse local exigir (inciso H). A vigilância sanitária é, dessarte, assunto de suma importância, tanto que o constituinte estabeleceu a participação dos três entes federativos para cuidar da matéria, tendo consagrado expressamente, no art. 197, da Lei Maior, como sendo de relevância pública as ações e serviços de saúde.

Com efeito, a Lei n. 9.782/99, que criou a Agência Nacional de Vigilância Sanitária, realizou significantes mudanças no sistema sanitário. A legislação federal até então conhecida foi quase toda editada há mais de vinte anos $^{(t)}$ e por isso se encontra, evidentemente, desatualizada. Uma série de situações atinentes à fiscalização de bens e serviços submetidos ao controle de vigilância sanitária não foi normatizada por essas leis, principalmente em razão da novidade de seus temas. Por conseguinte, é muito comum verificarmos certos serviços e produtos destinados à saúde e oferecidos à população, sem o devido controle legal, isto porque foram desenvolvidos e, ou, criados muito após a edição das referidas normas.

As autoridades sanitárias, por sua vez, clamavam por uma lei que Ihes contemplasse medidas coercitivas mais contundentes e eficazes para o exercício do poder de polícia, ${ }^{(1)}$ de maneira a possibilitar respostas rápidas

(4) SILVA, José Afonso. "Curso de Direito Constitucional Positivo", ga ed., Sāo Paulo: Malheiros, 1992.

(5) DALLARI, Sueli Gandolif. "Competência Municipal em Matéria de Saúde", Cadernos de Direito Municipal, pp. 413-415.

(6) Art. 23, da CF. "É competência comum da Uniāo, dos Estados, do Distrito Federal e dos Municípios: ... II - cuidar da saúde e assistência pública; ;..".

(7) DALLARI, Sueli Gandolfi, "Competència Municipal...", cit., pp. 172-177.

(8) Citamos como referências para este estudo: Prof. SILVA. José Afonso, "Curso de Direito...", cit.; MORAES, Alexandre. "Direito Constitucional". São Paulo, Atlas, 1997, pp. 279-280; ALMEIDA, Fernanda Dias Menezes de. "Competências na Constituição de 1988", São Paulo, Atlas, 1991, pp. 139. 171; BARROSO, Luiz Olavo. "Disposiçōes Constitucionais Transitórias. Delegaçōes Legislativas. Poder Regulamentar". Revista de Direito Público, vol. 23, n. 96, 1990, pp. 69-80.

(9) BASTOS. Celso Ribeiro, "Curso de Direito Administrativo". s.I., s.d., p. 277; DALLARI, Sueli Gandolfi. "Competência Municipal...", cit., p. 174.

(10) Algumas das principais leis federais que regulam a matéria sanitária são o Decreto-Lei n. 986/ 69, Lei n. 5.991/73, Lei n. 6.360/76, Lei n. 6.437/77 e Lei n. 8.080/90.

(11) Sobre conceito de Poder de Policia ver: MEIRELLES. Hely Lopes. "Poder de Polícia e seus Limites", RDA, $27 / 1$. 
às ações ilicitas e abusivas de empresas e profissionais. ${ }^{(12)}$ Foi, dessarte, dentro desse cenário que a Agência Nacional de Vigilância Sanitária (ANVISA) foi criada, ${ }^{(13)}$ tendo como inspiração o modelo americano da agência que controla e fiscaliza bens e produtos relacionados à saúde, FDA Food and Drug Administration. Objetivou-se, através da sua criação, dar mais poder e autonomia ao serviço de vigilância sanitária federal (anteriormente, as ações de vigilância sanitária na esfera federal eram exercidas pela extinta Secretaria Nacional de Vigilância Sanitária, do Ministério da Saúde), daí a natureza de autarquia(14) especial da agência, caracterizada pela independência administrativa, estabilidade de seus dirigentes e autonomia financeira(15). Espera-se, assim, que com todos esses atributos o sistema de vigilância sanitária possa ser, doravante, mais ágil e eficaz. Entretanto, cumpre verificar como se encontram adequadas essas competências atribuídas à Agência no ordenamento jurídico, especialmente ao constitucional.

\section{COMPETÊNCIA NORMATIVA DA AGÊNCIA NACIONAL DE VIGILÂNCIA SANITÁRIA}

Um dos grandes desafios do sistema de vigilância sanitária está na urgência de se normatizar bens e serviços relacionados direta ou indiretamente com a saúde da população, de modo a permitir um amplo exercício do poder de polícia sanitária sobre essas questões.

Contudo, a atividade legislativa demanda tempo, isto é, muitas vezes o prazo para aprovar-se uma lei não corresponde àquele necessário para atender às questões de interesse da saúde, cujas relevância e urgência são usuais. Para solucionar problemas dessa ordem é que o Legislador Federal atribuiu, através da Lei n. 9.782/99 (especialmente em seu art. $7^{\circ}$ ), competência regulamentar à Agência Nacional de Vigilância Sanitária, de modo a Ihe permitir o pleno exercício de polícia sanitária.

Não obstante a louvável solução encontrada pelo Legislador Federal para dar maior dinamismo ao sistema sanitário, permitindo à Agência normatizar as ações de vigilância sanitária, resta perquerir se esse exercício não seria excessivo, configurando uma espécie de delegação legislativa confrontante com a constituição, ou ainda, se não configuraria um desbordamento dos limites constitucionais regulamentares.

(12) Ver acontecimentos com falsificação de medicamentos: "Vigilância Sanitária admite erros", in Jornal do Brasil, RJ, de 10/07/98, pp. 1/4; "Máfia do remédio é mais forte que órgãos da saúde", in Jornal do Estado de Minas, MG, de 14/08/98, pp. 1/2; "Médicos não notificam problemas", in Jornal do Brasil, RJ, de 29/11/98, pp. 5/5.

(13) Lei n. $9.782 / 99$, art. $3^{\circ}$.

(14) MEIRELLES, Hely Lopes. "Poder de Polícia...", cit., p. 300.

(15) Parágrafo único do art. $3^{\circ}$, da Lei n. 9.782/99. 


\section{O PODER REGULAMENTAR}

Para uma melhor compreensão da questão colocada, qual seja, os limites constitucionais do poder regulamentar da Agência Nacional de Vigilância Sanitária, importante se faz o desenvolvimento desse estudo por meio da concepção do "Estado Democrático de Direito", também chamado de regime da legalidade, ${ }^{(16)}$ consagrado na Carta Magna de 1988.

Diz o texto constitucional que no Estado Democrático de Direito "ninguém será obrigado a fazer ou deixar de fazer alguma coisa senão em virtude de lei". (17) Partindo desse princípio basilar da organização democrática do Estado de Direito, denominado de princípio da legalidade, todas as atividades, quer do poder público, quer dos cidadãos, estão condicionadas a uma norma jurídica anteriormente posta. Esta foi a grande conquista política e jurídica dos nossos tempos contra o absolutismo estatal em que o Estado tudo podia, inobstante a inexistência de normas, conquanto que ao cidadão só era dado obedecer as ordens emanadas do poder estatal. Com o surgimento do Estado Democrático de Direito, tanto as atividades do Estado como as do particular passaram a ser tuteladas e obrigadas pela vontade do legislador. Trata-se, pois, do princípio do governo das leis, consagração máxima da tutela das liberdades públicas contra 0 absolutismo estatal.(18) Essa conquista política-jurídica, libertou o cidadão dos habituais arbítrios cometidos pelo soberano, o qual dirigia a vida do particular de acordo com a sua vontade pessoal. Nos dias de hoje, não se admite mais que os direitos individuais fiquem a mercê da vontade estatal (investida na atualidade, não mais na pessoa do soberano mas na da autoridade pública), a qual, demonstra a história, nem sempre representou de forma legitima os interesses do particular. Assim, de modo a garantir a legitimidade do direito posto, o poder constituinte estabeleceu, no parágrafo único, do artigo primeiro da Carta Magna, que "todo poder emana do povo, que o exerce por meio de representantes eleitos ou diretamente, nos termos desta Constituição", e esse poder no Estado de Direito Democrático deve ser exercido por leis. Somente elas poderão estabelecer deveres aos cidadãos. Para tanto, a lei é imprescindível, segundo o texto constitucional, não podendo nenhuma outra manifestação estatal, judiciária ou administrativa suprir sua ausência. ${ }^{(19)(20)}$

Para o Poder Público, todavia, o princípio da legalidade apresenta-se de forma um tanto quanto diversa, pois, conforme estabelece o art. 37, do diploma constitucional, a administração pública só poderá agir por determi-

(16) A esse respeito ver: LEAL, Victor Nunes. "Lei e Regulamento". In Problemas de Direito Público. Rio de Janeiro, Forense, 1960.

(17) Art. 5\%, inciso II, da Constituição Federal.

(18) BARROSO, Luiz Olavo. "Princípios da Legalidade. Delegaçỏes Legislativas. Poder Regulamentar. Repartição Constitucional das Competências Legislativas". Revista Forense, vol. 93, p. 204.

(19) LIMA, Ruy Cerne. "Principios de Direito Administrativo", cit., 4ª ed., p. 37.

(20) ATALIBA, Geraldo. "Decreto Regulamentar no Sistema Brasileiro", Revista Juridica da PGMSP, n. 2, junho 1996, p. 14. 
nação ou autorização legal. Destarte, a inexistência de lei significa para a administração pública a impossibilidade do exercício de sua atividade administrativa (princípio da legalidade da administraçāo(21) $)^{(22)}$

Portanto, diante do princípio da legalidade, balizador do Estado de Direito, cumpre indagar sobre o alcance do poder regulamentar. Poder-se-ia igualá-lo, em face de seu conteúdo normativo, a uma lei material emanada do executivo com poder coercitivo? Estariam os particulares, assim, sujeitos aos efeitos do regulamento executivo? Tomemos como premissa inicial, para responder a essas indagações, a definição conceitual de lei para, a seguir, traçar um pararelo com o regulamento executivo.

$\mathrm{Na}$ lição primorosa do eminente Professor Seabra Fagundes, verificamos que as leis são situações abstratamente consideradas que se acomodam às situações individuais e, por isso, são consideradas como fontes formadoras de direito. Acrescenta, ainda, que a lei deve ser compreendida tendo-se em vista o seu conteúdo material e formal. ${ }^{(23)}$ Nesse ponto, nos ensina o eminente jurista Vicente Ráo, que a lei em seu sentido formal é a "norma geral de direito formulada e promulgada, por modo autêntico, pelo órgão competente da autoridade soberana e feita valer pela proteção-coerção, exercida pelo Estado".(24)

A Constituição Federal elegeu como órgão competente para a elaboração das leis, o Poder Legislativo. Segundo o modelo da Separação de Poderes $^{(25)}$, adotada pelo nosso sistema constitucional, apenas o Poder Legislativo poderá inovar a ordem jurídica através de normas legais.

Portanto, lei em sentido formal é ato legislativo típico. Todavia, cumpre perquirir qual a extensão constitucional do poder regulamentar em relação à lei.

Diz supramencionado artigo que compete privativamente ao Presidente da República expedir Decretos e regulamentos para a fiel execução das Leis. Entendendo-se por decreto "a forma (veículo) de manifestação da vontade do Chefe do Executivo", enquanto o "regulamento é a matéria, o conteúdo" dessa vontade. ${ }^{(26)}$ Logo de plano observa-se, da simples leitura do texto constitucional mencionado, que o regulamento é ato administrativo cuja edição sucede à lei, uma vez que destina-se a sua fiel execução. Portanto,

(21) ATALIBA, Geraldo. "Decreto Regumentar...", cit.

(22) BARROSO, Luiz Olavo. "Principios da Legalidade...", cit.

(23) FAGUNDES, Miguel Seabra. "O Controle dos Atos Administrativos pelo Poder Judiciário", 4" ed., Rio de Janeiro, Forense, 1967, pp. 32-34.

(24) RÁO, Vicente. "O Direito e a Vida dos Direitos", $5^{\text {a }}$ ed., São Paulo, Revista dos Tribunais, 1999, pp. 282-283.

(25) Art. 2, CF. "Sāo Poderes da União, independentes e harmônicos entre si, o Legislativo, o Executivo e o Judiciario".

(26) ATALIBA, Geraldo. "Poder Regulamentar do Executivo". Revista de Direito Público, n. 57/58, Jan./Fev., 1981, pp. 187-189. 
seu âmbito de aplicação legal deve cingir-se aos limites da lei a que se deva regulamentar. ${ }^{(27)}$ Entretanto, resta conhecer esses limites legais.

Tomando como exemplo a Lei Federal n. 9.782/99 - objeto de nosso estudo - verifica-se que em vários momentos o Legislador Federal atribuiu poderes à Agência Nacional de Vigilância Sanitária para regulamentar determinados assuntos que não foram normatizados pelo referido texto legal.

É o caso, $v . g$. , do $\S 4^{\circ}$, do art. $8^{\circ}$, da mencionada lei, que estabelece que "a Agência poderá regulamentar outros produtos e serviços de interesse para o controle de risco à saúde (...)".

Assim, cumpre saber, todavia, se a Agência ao regulamentar um produto ou serviço, como quer o aludido texto legal, năo estaria ferindo o princípio constitucional da legalidade, o qual estabelece que apenas à lei é dado criar deveres ou obrigaçōes.

Pois bem, como visto, o regulamento tem por finalidade explicitar a lei, isto é, deve esclarecer o modo e a forma pela qual a lei será executada. Entretanto, se a Lei n. 9.782/99, em seu art. $8^{\circ}$, relacionou apenas alguns dos produtos que serão controlados pela a ANVISA, mas não todos, conforme se depreende do $\S 4^{\circ}$, do mesmo artigo, seria possível consideramos a "regulamentação" de outros produtos não contemplados pela legislação ordinária em referência como sendo uma espécie de explicitação ou esclarecimento de que fala a doutrina?

Vejamos. $O \S 1^{\circ}$, do art. $8^{\circ}$ em questão, enumera os bens e produtos submetidos ao controle e fiscalização sanitária pela Agência. Assim, pelo conceito de poder regulamentar, a Agência só poderá explicar ou esclarecer questões atinentes aos produtos e serviços já legalmente arrolados. A regulamentação de novos produtos não contemplados pela lei estaria, no que tange a noção de poder regulamentar, inovando a ordem jurídica. $O$ que, num primeiro momento, não se admite, uma vez que ao regulamentar um serviço ou produto não contemplado anteriormente pela lei a administração cria para si o dever de fiscalizá-lo e para o administrado a obrigação de submetê-lo ao controle e fiscalização da Agência, ou seja, inova a ordem jurídica, porque até então referido serviço ou produto estava livre de qual-

(27) A doutrina nesse sentido é pacífica, valendo ressaltar as valiosas manifestaçōes de importantes juristas a respeito do âmbito de aplicação do poder regulamentar: "(Regulamentos) não acarretam, nāo podem acarretar qualquer modificação à ordem juridica vigorante" (Seabra Fagundes); "O regulamento brasileiro nāo inova na ordem juridica (...). Eles devem estar ajustados à lei, nāo podem inovar ou criar obrigações; se o fizerem, serão ilegais" (Carlos Mario da Silva Velloso); "O regulamento é ato emanado do Executivo. destinado a explicitar, detaihar o modo e forma de execução da lei. Vale dizer: é ato interior à lei e a ela subordinado" (Luiz Olavo Barroso); "Os regulamentos são insuscetiveis de criar obrigaçōes novas, sendo apenas aptos a desenvolver as existentes na lei" (Celso Ribeiro Bastos); "Quando o constituinte pretendeu que o Executivo legislasse, criou instrumento especial - a medida provisória - para que dispusesse sobre certas matérias. (...). A lei inova a ordem jurídica infraconstitucional; o regulamento não a altera" (Michel Temer); "Onde se estabelecem, alteram-se ou extinguem-se direitos, não há regulamento - há abuso de poder regu. lamentar, invasão de competência legislativa" (Pontes de Miranda). 
quer controle. Ao assim proceder, a administração invadiu, segundo o princípio da legalidade e da separação dos poderes, o campo de atuação do legislador. Obviamente que, pelo exposto, o poder regulamentar não pode extinguir direitos ou criar deveres e obrigações. Ele deve cingir-se tão somente a uma pormenorização das condições de aplicação da lei, isto é, de seu conteúdo legal, de maneira a facilitar a sua execução. ${ }^{(28)}$

Não obstante essa certeza, é muito comum verificarmos regulamentos em pleno vigor, que excedem os estritos limites da lei. Vale destacar o Decreto n. 79.094/77, que regulamentou a Lei Federal n. 6.360/76, em seu art. 11. Segundo o referido artigo, os produtos afetos a Lei Federal em comento estão livres de autorização prévia quando importados por pessoas físicas, desde que não destinados ao comércio. Todavia, como pode-se observar do art. 11, da Lei Federal n. 6.360/66, essa exceção não foi prevista, o que significa dizer que todas as pessoas, físicas ou jurídicas, estão igualmente sujeitas a autorização prévia e expressa do Ministério da Saúde, no que concerne a importação de produtos afetos ao controle sanitário. Novamente, nos deparamos com a inovação do texto legal, por meio de um Decreto, o que não se admite.

Questões como estas vêm sendo amplamente debatidas e corrigidas pelos nossos tribunais, valendo trazer à colação importante julgado a respeito do tema, o qual, dentro da matéria sanitária, tem servido de paradigma a outras decisões. Trata-se do julgamento do Recurso Extraordinário de $n$. 87.200-1, em que se discutia o Decreto regulamentar n. 74.170/74. Entendeu a Segunda Turma Julgadora do Supremo Tribunal Federal, por maioria de votos, que o referido Decreto ultrapassou os lindes do poder regulamentar, inovando a ordem jurídica ao exigir a presença de assistente técnico em estabelecimentos comerciais, posto que referida situação não foi contemplada pela Lei n. 6.360/76.

A questão do poder regulamentar em matéria de vigilância sanitária é, como demonstra o julgado em comento, ainda mais complexa, suscitando muitos debates, pois sempre há a questão do interesse da saúde pública envolvido que, segundo alguns juristas, muitas vezes não pode esperar o trâmite normal do processo legislativo, vindo a contrastar essa questão, conseqüentemente, com o próprio princípio da legalidade.

Acreditamos, pois, que foi dentro dessa perspectiva que o Legislador Federal atribuiu competência à Agência Nacional de Vigilância Sanitária para dispor sobre determinados assuntos não contemplados pela Lei $\mathbf{n}$. 9.782/99, como v.g., no caso do art. $8^{\circ}, \S 4^{\circ} \stackrel{\circ}{ }$, citado anteriormente.

À primeira vista, quer nos parecer que o dispositivo em comento, ao atribuir competência à Agência para regulamentar outros produtos e serviços de interesse à saúde, acabou por delegar competência legiferante à Agência. 
Ocorre que a delegação legislativa em nosso sistema constitucional é proibida, salvo exceções expressamente enumeradas pela Constituição $\mathrm{Fe}$ deral. ${ }^{(29)}$ Essa vedação, como bem observou Luiz Olavo Barroso ${ }^{(30)}$, não vem contida expressamente na Carta Magna. Ela decorre da interpretação de outras normas e princípios constitucionais, como o da separação de poderes $^{(31)}$, da representação política ${ }^{(32)}$, da supremacia da Constituição e do devido processo legal(33). Ressalte-se, ademais, que o Constituinte houve por bem revogar, através do Ato das Disposições Constitucionais Transitórias, promulgado juntamente com a Carta Magna de 1988, todas as normas delegadoras de competência normativa, existentes até então.(34) Assim, diferentemente do que ocorre em outros países que aceitam a delegação legislativa ${ }^{(35)}$, o Brasil se mantém na posição de refutar (salvo nos casos previstos no art. 68 , da Lei Maior) a delegação legislativa ${ }^{(36)}$, em função da prevalência constitucional dos princípios da legalidade e da separação dos poderes $^{(37)}$.

Segundo a nossa Constituição, o Executivo só poderá legislar através de lei delegada por meio exclusivamente do Presidente da República, que é o único que detém competência para tanto. Além disso, trata-se de uma exceção, quase mesmo uma excepcionalidade, sendo que o seu exercício está condicionado à existência de uma delegação legislativa, que deverá ser solicitada pelo chefe do Poder Executivo ao Congresso Nacional|(38).

Deste modo, o ordenamento jurídico brasileiro refuta a possibilidade de atribuir-se poderes legiferantes delegados ao chefe da Agência Nacional de Vigilância Sanitária, ainda mais por meio de lei ordinária. Essa atribuição é dada pela Constituição e, exclusivamente, para o Presidente da República. ${ }^{(39)}$ Portanto, o $\S 4^{\circ}$, do art. $8^{\circ}$, da Lei n. 9.782/99, deverá, nesse aspecto, ser interpretado restritivamente, isto é, os outros produtos de que trata o artigo em comento, só poderão ser aqueles já cuidados nessa Lei ou em outra vigente. Não poderá a Agência fiscalizar ou controlar outros produtos não previstos em lei porque, do contrário, estaria inovando a ordem jurídica e, por conseguinte, afrontando o princípio constitucional da legalidade.

Uma vez consignado que o Decreto Regulamentar não pode ampliar ou restringir o conteúdo da lei, já que a ela está subordinado, resta estudar

(29) Art. 59, inciso IV, e 68, da CF.

(30) "Disposiçōes Constitucionais Transitórias...", cit., p. 207.

(31) Consagrado nos arts. $5^{\circ}$, inciso 11,37 e 84 , inciso IV, da CF.

(32) Art. 10, da CF.

(33) Art. $5^{9}$, inciso LV, da CF.

(34) Art. 25, das Disposiçōes Transitórias, da CF.

(35) Como exemplo de paises que aceitam a técnica ou modos de delegação legislativa, citamos a França, Estados Unidos, Inglaterra, Itălia, Alemanha etc.

(36) VELLOSO, Carlos Mário da Silva. "Delegação Legislativa. A Legislação por Associações", Revista de Direito Público, n. 90, Abr./Jun., 1989, p. 85.

(37) LEAL, Victor Nunes. "Lei e Regulamento", cit., p. 86

(38) MARIOTTI, Alexandre. "Medidas Provisórias", Sảo Paulo, Saraiva, 1999, p. 31

(39) BARROSO, Luiz Olavo. "Disposições Constitucionais...", cit. 
se, na inexistência de lei sobre determinado assunto relacionado à saúde pública, poder-se-ia cogitar da possibilidade da Agência Nacional de Vigilância Sanitária suprir essa lacuna, ainda que temporariamente, por meio de regulamento até o surgimento de uma lei que cuide da matéria. Trata-se de um tema delicado, que merece atenção, uma vez que a própria doutrina encontra-se dividida a respeito dessa questão.

Com efeito, no que se refere a viabilidade da fórmula de Montesquieu, que resultou na técnica do regulamento de execução, até aqui abordado, não restam dúvidas quanto a quase que absoluta unanimidade de sua aceitação pela doutrina. O regulamento de execução, como exposto, é um "ato administrativo normativo, contendo comandos gerais, com vistas à correta aplicação da lei"(40), o qual não pode ultrapassar os limites da legislação a que se destina regulamentar. Quanto a isso, não se discute. Entretanto, uma moderna corrente do direito cogita da possibilidade da aplicação de uma outra modalidade de regulamento, qual seja, a do regulamento autônomo ou independente, expedido pelo Poder Executivo para os fins de suprir eventuais lacunas ou ausência de lei. Regulamentos autônomos, já ensinava Rui Barbosa, são "aqueles em que o poder executivo obra sôbre si nos vários domínios da administração pública, ainda não ocupados pela legislação"(41).

Exatamente com o fulcro de atender à urgência de determinados assuntos em benefícios da coletividade, que não podem aguardar sine die pela edição e promulgação de uma lei que os regularize, é que expressiva corrente de juristas vêm sustentando a possibilidade do Chefe do Executivo editar regulamentos autônomos ou independentes, para o fiel cumprimento de sua atividade administrativa.

O seu fundamento, conforme a visão do Professor Sérgio Ferraz, está arraigado na "teoria da determinação legal ou constitucional" que consiste, em verdade, no dever de agir do Poder incumbido da tarefa administrativa. Segundo essa posição, a administração precisa expedir regulamento autônomo, para prover situações não contempladas em lei, de modo a lhe permitir o fiel cumprimento do exercício de sua atividade administrativa ${ }^{(42)}$. Todavia, essa posição encontra forte resistência na doutrina. A problemática reside no fato da Constituição Federal estabelecer em seu art. 84, inciso IV, que o regulamento será expedido para fiel execução da Lei. Desse modo, pelo que entende a corrente majoritária da doutrina, não há como se cogitar da possibilidade de edição de um regulamento que não se conecte em nada com qualquer Lei. ${ }^{(43)}$

(40) FERRAZ, Sérgio. "Regulamento. Três Estudos de Direito", 1977, p. 115.

(41) In "Vitaliciedade de Funcionário Público. Extensão e Limites da Açāo Regulamentar do Poder Executivo". Revista Forense, vol. 7, Jan./Jul., 1907, pp. 33-46.

(42) FERRAZ, Sergio. "Regulamento...", cit., pp. 116-118.

(43) ATALIBA, Geraldo. "Poder Regulamentar...", cit., p. 197. 
Já aqueles que aceitam a possibilidade de edição do regulamento autônomo (v. g., Sérgio Ferraz, Hely Lopes Meirelles, Francisco Campos, Diógenes Gasparini, Alexandre Mariotti etc. $)^{(44)}$ fazem a ressalva de que tal regulamento não poderá dispor sobre matérias onde haja expressa reserva de lei (princípio da reserva de lei), assim como não poderá regulamentar assunto já tratado em lei (princípio da preeminência da lei), do mesmo modo em que não pode ser contra legem. Deve, assim, operar intra legem e secundum legem, e de maneira alguma deverá dispor sobre questões que limitem direitos individuais, posto que essa matéria é de exclusividade da legislação formal, ou seja, da lei em si. ${ }^{(45)}$

Os defensores do regulamento autônomo reconhecem, todavia, a existência de alguns requisitos essenciais que devem ser observados para edição dessa modalidade de regulamento, quais sejam: a) não cuidar de matéria de reserva legal ${ }^{(46)}$; b) necessidade da omissão do legislador a respeito do tema a ser versado no regulamento ${ }^{(47)}$; c) ter a matéria o caráter de urgência, em benefício da coletividade e uma atividade concreta ou normativa, da Administração Pública; d) não cuidar de questões que envolvam limites aos direitos individuais; e ainda, e) ser emitido pelo Chefe do Executivo, isto é, pelo Presidente da República. ${ }^{(48)}$

Dentro dessa concepção, poder-se-ia admitir a edição de regulamentos autônomos no âmbito da saúde, para atender àquelas questões de urgência, onde não existe lei tratando da matéria. Todavia, existe um complicador no que diz respeito à possibilidade da Agência Nacional de Vigilância Sanitária editar regulamentos autônomos, ainda que admitindo-se a tese que acolhe essa modalidade de regulamento. Trata-se da questão da competência para a expedição do regulamento autônomo. Reza a Constituição Federal, em seu art. 84, inciso IV, que apenas o Chefe do Executivo possui competência para emitir regulamentos dessa natureza, no caso, o Presidente da República. Vem entendendo a doutrina que estariam igualmente comparados a essa situação os chefes do executivo, nas demais esferas do governo, em relação às legislações estaduais, o Governador do Estado, e municipais, o Prefeito. ${ }^{(49)}$

Quer nos parecer, contudo, que essa questão torna-se insuperável no que diz respeito à competência do chefe da Agência Nacional de Vigilância Sanitária para expedir regulamentos autônomos. Isto porque, a Constituição Federal não equipara os chefes de órgãos públicos ao Chefe do Execu-

(44) ATALIBA, Geraldo. "Poder Regulamentar...", cit., p. 197.

(45) WALD, Arnold. "Ato Vinculado e Direito Adquirido. Limitaçōes ao Poder Regulamentar", São Paulo, Revista dos Tribunais, vol. 80, n. 664, Fev./1991, p. 15.

(46) Art. $68, \S 1^{\circ}$, da CF.

(47) LEAL, Vitor Nunes observa que, "se já existe lei sobre a matéria, tem o regulamento de conformar-se com as suas disposiçōes". "Lei e Regulamento", cit., p. 85.

(48) Veja-se alguns comentários a respeito do tema: FERRAZ, Sérgio ("Regulamento...", cit., p. 120), BARROSO, Luiz Olavo ("Principios da Legalidade...", cit., pp. 210-211); LEAL, Victor Nunes (“Lei e Regulamento...", cit., pp. 79-81).

(49) Idem 
tivo, que é um só: o Presidente da República. Se fosse outra a vontade do constituinte, não teria dito expressamente, no artigo supramencionado, competir "privativamente ao Presidente da República" a expedição de regulamentos. ${ }^{(50)}$

Não obstante esta constatação, observamos na prática que órgãos da administração pública vêm habitualmente expedindo portarias com o intuito de regulamentar certas matérias, equiparando esse instrumento ao regulamento previsto no art. 84 , inciso IV, da Lei Maior, não fugindo à regra, a Agência Nacional de Vigilância Sanitária, como pode-se observar das constantes portarias e resoluções por ela editadas e publicadas em Diário Oficial da União, ao longo de sua criação. ${ }^{(51)}$

Ocorre que as portarias, segundo lição de Hely Lopes Meirelles, "são atos administrativos internos, pelos quais os chefes de órgãos, repartições ou serviços expedem determinações gerais ou especiais a seus subordinados". E acrescenta, "as portarias, como demais atos administrativos internos, não atingem nem obrigam aos particulares, pela manifesta razão de que os cidadãos não estão sujeitos ao poder hierárquico da Administração Pública. Nesse sentido vem decidindo o supremo Tribunal Federal (STF-RF $107 / 65$ e 277, 112/202)".

Isto posto, conclui-se que a Agência Nacional de Vigilância Sanitária não possui competência constitucional para expedir regulamentos, de acordo com o art. 84, inciso IV, da Carta Magna e, ademais, conforme os ensinamentos do Prof. Hely Lopes Meirelles, acima citado, a portaria não pode ser equiparada ao conteúdo constitucional atribuído ao regulamento, em função do seu conteúdo e campo de abrangência.

Do mesmo modo as resoluções que vêm sendo comumente editadas pela Agência Nacional de Vigilância Sanitária não podem ser equiparadas ao regulamento constitucional em apreço, por idênticos fundamentos. ${ }^{(52)}$

Ainda visando a solucionar a legalidade da edição de regulamento pela Agência Nacional de Vigilância Sanitária, alguns estudiosos da matéria vêm sustentando em seminários a constitucionalidade dessa atribuição pela lei (aos moldes do art. $8^{\circ}, \S 4^{\circ}$, da Lei n. 9.782/99, anteriormente mencionada), sem que ocorra quebra do princípio da legalidade e da reserva legal, por entender que esse poder, conferido à administração pública, assemelha-se àqueles atribuídos pela norma penal em branco ou, ainda, pelo tipo penal aberto.

Com efeito, a norma penal em branco é aquela que para ser aplicada necessita ser complementada por outra disposição normativa. Essa complementação, segundo alguns doutrinadores, não estaria ofendendo o princípio

(50) Idem.

(51) Servem de exemplo as Resoluções ns. 03/99, 09/99, 19/99, RDC 23/99 e 391/99.

(52) GASPARINI, Diógenes. "Poder Regulamentar", 2ª ed., Sāo Paulo, Revista dos Tribunais, 1982, p. 120 
da reserva legal, podendo ser realizada de "três maneiras: a) por disposição prevista na mesma lei; b) por disposição contida em outra lei; c) por disposição emanada de outro poder, ou seja, de um ato administrativo". Explica a doutrina que existem "condutas que não se podem descrever sem acudir a esta técnica, dada sua complexidade (no meio ambiente, por exemplo, o conceito conexo de contaminação só pode ser determinado mediante uma remissão a outras normas)". ${ }^{(53)}$ Já para o tipo penal aberto, esclarece Heleno Cláudio Fragoso que existem tipos em que "não aparece expressa, por completo, a norma que o agente transgride com seu comportamento, de tal maneira que não se contém no tipo a descrição completa do comportamento delituoso, que depende da transgressão de normas especiais que o tipo pressupōe", concluindo que, "nos casos de tipos abertos, a ilicitude deve ser estabelecida pelo juiz, verificando se houve a transgressão das normas que a incriminação pressupõe". ${ }^{(54)}$

Em que pese a tese lançada, quer nos parecer que os seus fundamentos bem se aplicariam às questões pertinentes à tipificação de crimes cometidos em matéria de vigilância sanitária. Entretanto, no que diz respeito ao controle e fiscalização de bens e serviços afetos à vigilância sanitária, tratase, em verdade, de atividade restrita ao direito administrativo, ao qual não se aplicam àqueles institutos exclusivos - ainda que mesmo lá, muito contestados - do direito penal. De qualquer sorte, o tema merece, em outra oportunidade, maior aprofundamento.

\section{CONCLUSÕES}

Por todo o exposto, concluímos que o sistema jurídico brasileiro não admite a possibilidade de edição de regulamentos que inovem a ordem juridica, salvo quando realizada dentro das exceções anteriormente comentadas. Entretanto, é forçoso reconhecer a necessidade de uma agilidade quanto à aprovação de medidas administrativas que garantam ao chefe da Agência Nacional de Vigilância Sanitária uma maior efetividade na execução das atividades sanitárias.

Dentro dessa ótica é que moderna corrente doutrinária vem considerando as normas de vigilância sanitária como típicas de um Direito Peculiar, qual seja, o Direito Sanitário Regulamentar. Cumpre destacar, como referência desse novo entendimento doutrinário, o pensamento do prestigiado Professor Sebastião Botto de Barros Tojal, que de maneira inovadora concluiu que "especialmente no campo da saúde pública, é absolutamente imperativo reconhecer que sua proteção se faz exata e precisamente pela compreensão de que as normas típicas do que já se definiu como Direito Sanitá-

(53) FREITAS, Viadimir Passos, e PASSOS, Gilberto. "Crimes Contra a Natureza", 6ã ed., São Paulo, Revista dos Tribunais, 1999, p. 34.

(54) FRAGOSO, Heleno Cláudio. "Lições de Direito Penal", 1998, p. 183. 
rio não se conformam aos modelos clássicos de um Direito concebido à luz de paradigmas estatutários, informados por princípios como certeza e segurança jurídicas, já que é inerente a esse processo de rematerialização da racionalidade legal o particularismo, a legitimidade determinada pela observância de critérios fundados em uma ética de convicção...", acrescentou, referindo-se ao pensamento de Gunther Teubner, que "juridificação não significa apenas crescimento do Direito, mas designa antes um processo no qual o Estado Social intervencionista cria um novo tipo de Direito, o Direito Regulatório. Apenas quando ambos estes elementos - materialização e finalismo político-intervencionista - são tomados em atenção conjuntamente, poderemos entender a verdadeira e específica natureza do contemporâneo fenômeno da juridificação. Em suma, o Direito regulatório - que 'especifica coercitivamente a conduta social em ordem à consecução de determinados fins materiais' - caracteriza-se pelo primado da racionalidade material relativamente à racionalidade formal e pode ser definido de acordo com os seguintes aspectos: no plano de sua função, é um Direito associado às exigências de direção e conformação social, próprias do Estado Social; no de sua legitimação, é um Direito onde assumem fundamental relevo os efeitos sociais despoletados pelas suas próprias regulações conformadoras e compensadoras; finalmente, no plano de sua estrutura, o Direito regulatório afigura-se como um Direito 'particularísitico', finalisticamente orientado e tributários das ciências sociais". (55)

Comungamos da opinião do Professor Sebastião Tojal, acima citada, de que o Direito Sanitário tem características próprias e por isso deve ser considerado como sendo um Direito específico, no caso, Direito Sanitário Regulatório, que compreende muitos aspectos do direito administrativo, porém, congrega outras peculiaridades, previstas no próprio texto constitucional ${ }^{(56)}$, que vão além das circunstâncias de ordem meramente administrativas. O tratamento do Direito Sanitário regulatório, numa visão apenas administrativa, reduz suas potencialidades, prende o seu desenvolvimento exclusivamente no Direito Administrativo, quando ele comporta, em verdade, matéria multidisciplinar, finalisticamente voltado à proteção da saúde pública, que é o único direito qualificado pela constituição como de relevância pública. Todavia, apesar da inovação que comporta o tema, não podemos perder de vista que o princípio constitucional da legalidade é fonte basilar do nosso ordenamento jurídico, o que implica, num primeiro momento, dizer que a fonte formadora do direito será, via de regra, sempre a lei, emanada do Poder Legislativo.

(55) TOJAL, Sebastião Botto de Barros. "O moderno Direito Sanitário como expressão legítima de um Direito Regulatório, cujo fundamento é a própria Constituição Dirigente". In Os 10 Anos da Constituição Federal - Temas Diversos. Alexandre de Moraes (org.). São Paulo, Atlas, 1999, pp. $11-12$.

(56) TOJAL, Sebastiāo Botto de Barros. "O moderno Direito Sanitário...", cit., pp. 11-12. 


\section{REFERÊNCIAS BIBLIOGRÁFICAS}

ALMEIDA, Eurivaldo Sampaio, et al. "Distritos Sanitários: Concepção e Organização". São Paulo: Fundação Peirópolis, 1998, vol. 1.

ALMEIDA, Fernanda Dias Menezes de. "Competências na Constituição de 1988". São Paulo: Atlas, 1991.

ANDRADE, José Carlos Vieira de, et al. "Autonomia Regulamentar e Reserva de Lei". In Boletim da Faculdade de Direito Universidade de Coimbra - Estudos em Homenagem ao Prof. Doutor Afonso Rodrigues Queiró, n. especial, Coimbra, 1984, vol. I.

ATALIBA, Geraldo. "República e Constituição". São Paulo: Malheiros, 1985 (2 ed., 1998).

. "Decreto Regulamentar no Sistema Brasileiro". Revista Jurídica da Procuradoria Geral do Município de São Paulo, n. 2, Jun. 1996.

. "Poder Regulamentar do Executivo". Revista de Direito Público, n. 57/58, Jan./Fev. 1981.

"Regulamento no Direito Brasileiro". Revista Forense, vol. 297, Jan./Mar. 1987.

BARROSO, Luiz Olavo. “Disposições Constitucionais Transitórias. Delegações Legislativas. Poder Regulamentar". Revista de Direito Público, vol. 23, n. 96, 1990.

. "Princípios da Legalidade. Delegações Legislativas. Poder Regulamentar. Repartição Constitucional das Competências Legislativas". Revista Forense, vol. 93, n. 337, Jan./Mar. 1997.

BASTOS, Celso Ribeiro. "Curso de Direito Administrativo". s.I., s.d. (2a ed., São Paulo: Saraiva, 1996).

CAMPOS, Francisco. "Lei e Regulamento". Revista de Direito Administrativo, n. $80,1965$.

CARDOZO, José Eduardo Martins. "Princípios Constitucionais Explícitos. Princípio da Legalidade". In VVAA, Os 10 anos da Constituição Federal, Alexandre de Moraes (org.), São Paulo: Atlas, 1999.

CAVALCANTI, Themístocles Brandão, et al. "O Princípio da Separação dos Poderes e sua Modernas Aplicações". In Cinco Estudos. Rio de Janeiro: Fundação Getúlio Vargas, 1955.

CÉSAR, Afonso. "Do Poder Regulamentar". Revista de Informação Legislativa, vol. 32, n. 128, Out./Dez. 1995.

DALLARI, Sueli Gandolfi. "Competência Municipal em Matéria de Saúde". Cadernos de Direito Municipal. 
EDUARDO, Maria Bernadete de Paula, e MIRANDA, Isaura Cristina Soares de. "Vigilância Sanitária". Sāo Paulo: Fundação Peirópolis, 1998, vol. 8.

FAGUNDES, Miguel Seabra. "O Controle dos Atos Administrativos pelo Poder Judiciário". Rio de Janeiro: Forense, 1941 (4ª ed., 1967).

FERRAZ, Sérgio. "Regulamento. Três Estudos de Direito", 1977.

FERRAZ JR., Tercio Sampaio. "Teoria da Norma Juridica. Ensaio de Pragmática da Comunicação Normativa". Rio de Janeiro: Forense, 1978 (3 ${ }^{\text {a }}$ ed., 1997).

FERREIRA FILHO, Manoel Gonçalves. "Curso de Direito Constitucional". s.I., s.d. (17 $7^{\mathrm{a}}$ ed., São Paulo: Saraiva, 1989).

FERREIRA, Pinto. "Curso de Direito Constitucional". Rio de Janeiro: Freitas Bastos, 1964 (5 $5^{\mathbf{a}}$ ed., São Paulo: Saraiva, 1991).

FRAGOSO, Heleno Cláudio. “Lições de Direito Penal”. s.I., s.d., 1998, vol. I.

FREIRE, Homero. "A Constituição e o Poder Regulamentar". Revista Trimestral de Jurisprudência dos Estados. São Paulo, vol. 10, n. 37, Mar./Abr. 1986.

FREITAS, Vladimir Passos e PASSOS, Gilberto. "Crimes Contra a Natureza". 6" ed. São Paulo: Revista dos Tribunais, 1999.

GASPARINI, Diógenes. "Poder Regulamentar". São Paulo: Revista dos Tribunais, s.d. (2a ed., 1982).

JACQUES, Paulino. "A Competência no Estado Federal: Natureza Jurídica e Técnica". In Curso de Direito Constitucional. São Paulo: Forense, 1956 (3ª ed., 1962).

LEAL, Victor Nunes. "Lei e Regulamento". In Problemas de Direito Público. Rio de Janeiro: Forense, 1960. . "Lei e Regulamento". Revista de Direito Administrativo, n. 1, 1945.

LIMA, Ruy Cirne. "Princípios de Direito Administrativo". São Paulo: Revista dos Tribunais, s.d. (5 ed., 1982).

MARIOTTI, Alexandre. "Medidas Provisórias". São Paulo: Saraiva, 1999.

MEIRELLES, Hely Lopes. "Direito Administrativo Brasileiro". São Paulo: Revista dos Tribunais, 1964 (14 $4^{a}$ ed. atual. pela Constituição Federal de 1988, 1988). . "Poder de Polícia e seus Limites", RDA.

MELLO, Celso Antônio Bandeira de. "Curso de Direito Administrativo". São Paulo: Malheiros, 1980 (8" ed., 1996). 
"Poder Regulamentar ante o Princípio da Legalidade". Revista Trimestral de Direito Público, vol. 93, n. 4, 1998.

MIRANDA, Pontes de. "Comentários à Constituição de 1946". Rio de Janeiro: Imprensa Nacional, 1947, vols. I e III.

MORAES, Alexandre. "Direito Constitucional". São Paulo: Atlas, 1997 (6ª ed., revista, ampliada e atualizada com a EC n. 22/99, 1999).

MORAES, Germana de Oliveira. "Controle Jurisdicional da Administração Pública”. São Paulo: Dialética, 1999.

MOREIRA NETO, Diogo de Figueiredo. "Competência Concorrente Limitada". Revista de Informação Legislativa, Brasília, a. 25, n. 100, Out./Dez. 1988.

NETTO, André Luiz Borges. “Competências Legislativas dos Estados-Membros". São Paulo: Revista dos Tribunais, 1999.

PIÑA, Kenneth R. e PINES, Wayne L. "A Practical Guide. To Food and Drug Law and Regulation". Washington, D.C.: FDLI, 1998.

RÁO, Vicente. "O Direito e a Vida dos Direitos". 5ª ed. São Paulo: Revista de Tribunais, 1999.

SANTOS, Guido Ivan de Carvalho Lenir. "Comentários à Lei Orgânica da Saúde (Leis 8.080/90 e 8.142/90) - Sistema Único de Saúde". São Paulo: Hucitec, 1992 ( $2^{\text {a }}$ ed., 1995).

SILVA, Carlos Medeiros. "O Poder Regulamentar e sua Extensão". Revista de Direito Administrativo, vol. 20.

. "O Poder Regulamentar no Direito Comparado". Revista de Direito Administrativo, vol. 30.

SILVA, José Afonso. "Aplicabilidade das Normas Constitucionais". São Paulo: Revista dos Tribunais, 1968 (2 ed., 1982).

_. "Curso de Direito Constitucional Positivo". 9a ed. São Paulo: Malheiros, 1992.

SUNDFELD, Carlos Ari. "Sistema Constitucional das Competências". Revista Trimestral de Direito Público, n. 1, 1993.

TÁCITO, Caio. "O Estatuto e o Poder Regulamentar". Revista de Direito Administrativo, vol. 34.

TEMER, Michel. "Elementos de Direito Constitucional". São Paulo: Malheiros, 1982 (11 a ed., 1995).

TOJAL, Sebastião Botto de Barros. "O moderno Direito Sanitário como expressão legítima de um Direito Regulatório, cujo fundamento é a própria Constituição Dirigente". In VVAA, Os 10 anos da Constituição Federal, Alexandre de Moraes (org.). São Paulo: Atlas, 1999. 
VELLOSO, Carlos Mário da Silva. "Delegação Legislativa. A Legislação por Associações". Revista de Direito Público, n. 90, Abr./Jun. 1989.

WALD, Arnoldo. "Ato Vinculado e Direito Adquirido. Limitações ao Poder Regulamentar". São Paulo: Revista dos Tribunais, vol. 80, n. 664, Fev. 1991.

WALDMAN, Eliseu Alves e ROSA, Tereza Etsuko da Costa. "Vigilância em Saúde Pública". São Paulo: Fundação Peirópolis, 1998, vol. 7.

XAVIER, Alberto. "Conferências e Debates - Legalidade e Tributação". Revista de Direito Público, n. 47/48, Jun./Dez. 1978. 